\title{
PENGENDALIAN HAMA EPILACHNA SP PADA TANAMAN TERONG (Solanum Melongena) DENGAN PESTISIDA NABATI EKSTRAK BIJI JENGKOL DAN WAKTU APLIKASINYA
}

\author{
Sri Handayani ${ }^{1}$, Nuryulsen Safridar ${ }^{2}$ \\ 1 Program Studi Agroteknologi Fakultas Pertanian, Universitas Jabal Ghafur \\ E-mail :s.handayani2000@gmail.com \\ 2 Program Studi Agroteknologi Fakultas Pertanian, Universitas Jabal Ghafur
}

\begin{abstract}
ABSTRAK
Sri Handayani. Pengendalian Hama Epilachna sp Pada Tanaman Terong (Solanum melongena) Dengan Pestisida Nabati Ekstrak Biji Jengkol dan Waktu Aplikasinya. Penelitian ini bertujuan untuk melihat sejauh mana pestisida nabati ekstrak biji jengkol bisa mengendalikan intensitas serangan hama epilachna sp dengan mengatur waktu aplikasi yang tepat pada tanaman terong. Penelitian ini rencanaya akan dilaksanakan di Desa Simbe Kecamatan Mutiara Timur. Waktu penelitian dilaksanakan pada bulan April 2017 sampai dengan bulan Juni 2017. (Yogyakarta 2012). Bahan-bahan yang digunakan dalam penelitian ini adalah: benih terong ungu varietas Hibrida Panah Merah, biji jengkol, pupuk kandang, tanah dan air, pupuk NPK. Alat-alat yang digunakan dalam penelitian ini adalah cangkul, parang, gunting, polibag, blender, kain saringan, ember, gembor, hand sprayer, inseknet, kamera, papan nama penelitian dan papan nama plot, alat tulis menulis dan alat-alat lain yang diperlukan untuk menunjang penelitian ini. Penelitian ini menggunakan Rancangan Acak Kelompok (RAK) pola faktorial, ada 2 faktor yang diteliti yaitu faktor konsentrasi ekstrak biji jengkol terdiri dari 4 taraf dan faktor waktu aplikasi terdiri dari 4 taraf. Parameter yang diamati meliputi: intensitas serangan Hama epilchna sp, jumlah hama epilachna sp yang mati dan tinggi tanaman terong pada umur 30, 40, 50, dan 60 HST.
\end{abstract}

Keyword: pestisida nabati, jengkol, epilachna

\section{PENDAHULUAN}

\section{Latar Belakang}

Terong yang dimanfaatkan untuk hidangan makanan adalah bijinya. Terong dikonsumsi setelah disayur, digoreng atau untuk lalapan langsung dalam keadaan mentah. Terong dapat dipergunakan sebagai obat diantaranya untuk mengobati wasir, tekanan darah rendah, obat gatal, obat cuci perut, dan mengeringkan kulit muka berlemak. Dalam membudidayakan terong sering mengalami kendala gangguan organisme pengganggu tanaman (OPT). Salah satu jenis OPT pada tanaman terong yaitu hama kumbang daun (Epilachna sp), yang menyerang tanaman dengan menggigit permukaan daun sebelah bawah. Bila serangan berat dapat merusak semua jaringan daun dan tinggal tulang-tulang daun saja.
Hal ini tentu saja merugikan karena berdampak pada penurunan produksi tanaman.

Berbagai usaha untuk mengendalikan organisme pengganggu tanaman terong telah dilakukan, namun sampai saat ini masih tetap bertumpu pada penggunaan pestisida. Penggunaan pestisida yang terus menerus pada tanaman terong akan mengakibatkan biaya produksinya meningkat, sehingga mengakibatkan harga produksi sayuran menjadi tinggi. (Srinivasan, 2009).

Penggunaan pesitisida sintesis berdampak besar terhadap lingkungan maupun hama non target. Dampak negatif terhadap organisme non target meliputi dampak terhadap lingkungan berupa pencemaran dan menimbulkan keracunan bahkan dapat menimbulkan kematian bagi manusia (Tarumingkeng, 1992). Quijano et.al. (2001) juga menyatakan bahwa 
penggunaan pestisida memang memberikan keuntungan secara ekonomis, namun juga memberikan kerugian diantaranya residu yang tertinggal tidak hanya pada tanaman, tapi juga air, tanah dan udara.

Jengkol merupakan salah satu jenis tumbuhan yang memiliki potensi sebagai pestisida nabati. Zat yang terkandung pada tanaman jengkol antara lain protein, kalsium, fosfor, asam jengkolat, vitamin A dan B1, karbohidrat, minyak atsiri, saponin, alkaloid, terpenoid, steroid, tanin, dan glikosida. Dengan kandungan zat-zat tersebut, jengkol berpotensi sebagai bahan obat. (Pitojo, 1994).

Berdasarkan uraian di atas, penulis tertarik untuk melakukan penelitian dengan judul Pengendalian Hama Epilachna sp Pada Tanaman Terong (Solanum melongena) Dengan Pestisida Nabatai Ekstrak Biji Jengkol dan Waktu Aplikasinya.

\section{Tujuan Penelitian}

Penelitian ini bertujuan untuk melihat sejauh mana pestisida nabati ekstrak biji jengkol bisa mengendalikan intensitas serangan hama epilachna sp dengan mengatur waktu aplikasi yang tepat pada tanaman terong.

\section{Manfaat Penelitian}

Hasil penelitian ini diharapkan dapat bermanfaat sebagai inovasi baru dalam hal pengendalian hama khususnya hama Epilachna sp pada tanaman terong dengan menggunakan pestisida nabati.

\section{Rumusan Masalah}

Sejauh mana pengaruh ekstrak biji jengkol untuk mengendalikan intensitas serangan hama Epilachna sp pada tanaman terong dengan mengatur waktu aplikasinya.

\section{Hipotesis}

Diduga ekstrak biji jengkol dan waktu aplikasinya berpengaruh terhadap pengendalian hama Epilachna sp pada tanaman terong.

\section{METODE PENELITIAN \\ Tempat Dan Waktu}

Penelitian ini dilaksanakan di Desa Simbe Kecamatan Mutiara Timur. Waktu penelitian dilaksanakan pada bulan April 2017 sampai dengan bulan Juni 2017.

\section{Bahan dan Alat \\ Bahan}

Bahan-bahan yang digunakan dalam penelitian ini adalah: benih terong ungu varietas Hibrida Panah Merah, biji jengkol, pupuk kandang, tanah dan air, pupuk NPK.

\begin{abstract}
Alat-alat
Alat-alat yang digunakan dalam penelitian ini adalah cangkul, parang, gunting, polibag, blender, kain saringan, ember, gembor, hand sprayer, inseknet, kamera, papan nama penelitian dan papan nama plot, alat tulis menulis dan alat-alat lain yang diperlukan untuk menunjang penelitian ini.
\end{abstract}

\section{Rancangan Penelitian}

Penelitian ini menggunakan Rancangan Acak Kelompok (RAK) pola faktorial, ada 2 faktor yang diteliti yaitu faktor konsentrasi ekstrak biji jengkol terdiri dari 4 taraf dan faktor waktu aplikasi terdiri dari 4 taraf.

a. Faktor konsentrasi ekstrak biji jengkol

$(\mathrm{K})$, terdiri dari empat taraf, yaitu:

$$
\begin{array}{ll}
-\mathrm{K} 0 & =0(\mathrm{kontrol}) / \mathrm{polibag} \\
-\mathrm{K} 1 & =20 \% / \text { polibag } \\
-\mathrm{K} 2 & =40 \% / \text { polibag } \\
-\mathrm{K} 3 & =60 \% / \text { polibag }
\end{array}
$$

b. Faktor waktu aplikasi, terdiri dari empat taraf, yaitu:

$$
\begin{aligned}
& -\mathrm{W} 1=20 \mathrm{HST} \\
& -\mathrm{W} 2=30 \mathrm{HST} \\
& -\mathrm{W} 3=40 \mathrm{HST} \\
& -\mathrm{W} 4=50 \mathrm{HST}
\end{aligned}
$$$$
\text { Dengan demikian terdapat } 16
$$
perlakuan dan 2 kali ulangan sehingga diperoleh 32 satuan percobaan. Setiap perlakuan terdiri dari 2 polibag tanaman sampel atau terdapat 64 polibag tanaman sampel. 


\section{Pelaksanaan Penelitian}

Kegiatan penelitian antara lain: (1) Persiapan Media Persemaian dan Perlakuan Benih (2) Persiapan Media Tanam di Polibag (3) Pemupukan (4) Pembiakan Epilachna sp (5) Infestasi Hama Epilachna sp (6) Aplikasi Ekstrak Biji Jengkol (7) Pemeliharaan

\section{Pengamatan}

Parameter yang diamati meliputi:

1. Intensitas Serangan Epilachna sp

Pengamatan intensitas serangan dilakukan 10 hari setelah aplikasi pestisida nabati yaitu umur 30, 40, 50 dan 60 HST. Pengamatan dilakukan dengan cara mengamati setiap tanaman dan menghitung tingkat serangan OPT menggunakan rumus kerusakan tidak mutlak sebagai berikut:

$$
\mathrm{I}=\frac{\mathrm{ni} \times \mathrm{vi}}{\mathrm{Z} \times \mathrm{N}} \times 100 \%
$$

Dimana :

I = Intensitas kerusakan

ni = Jumlah tanaman atau bagian tanaman yang rusak pada tingkat skala kerusakan

vi $=$ Nilai skala kerusakan

$\mathrm{N}=$ Jumlah tanaman yang diamati

$\mathrm{Z}=$ Skala kerusakan tertinggi

2. Jumlah hama epilachna sp yang mati pada setiap tanaman sampel setelah aplikasi penyemprotan pada umur 30, 40, 50, dan 60 HST.

3. Tinggi tanaman pada umur 30, 40, 50 dan 60 HST. Pengukuran dilakukan mulai dari leher akar sampai titik tumbuh tertinggi dan dinyatakan dalam satuan $\mathrm{cm}$.

\section{HASIL PENELITIAN DAN \\ PEMBAHASAN \\ Pengaruh Konsentrasi Ekstrak Biji Jengkol}

Intensitas Serangan Hama Epilachna sp

Hasil analisis sidik ragam (Tabel Lampiran 2, 4, 6 dan 8) menunjukan bahwa konsentrasi ekstrak biji jengkol berpengaruh sangat nyata terhadap intensitas serangan hama Epilachna sp umur 30, 40, 50 dan 60 HST. Rata-rata intensitas serangan hama Epilachna sp akibat konsentrasi ekstrak biji jengkol dapat dilihat pada tabel berikut.

Tabel 2. Rata-Rata Intensitas Serangan Hama Epilachna sp (\%) akibat Konsentrasi Ekstrak Biji Jengkol

\begin{tabular}{|c|c|c|c|c|c|}
\hline \multirow[b]{2}{*}{ No } & \multirow[b]{2}{*}{ Perlakuan } & \multicolumn{4}{|c|}{ Intensitas Serangan (\%) } \\
\hline & & 30 HST & $\begin{array}{c}40 \\
\text { HST }\end{array}$ & $\begin{array}{c}\text { 50 } \\
\text { HST }\end{array}$ & $\begin{array}{c}60 \\
\text { HST }\end{array}$ \\
\hline 1 & $\mathbf{K}_{\mathbf{0}}$ & $61,91 \mathrm{c}$ & 7,99 b & $6,73 \mathrm{c}$ & $7,93 \mathrm{~d}$ \\
\hline 2 & $\mathbf{K}_{1}$ & $30,63 \mathrm{~b}$ & $6,67 \mathrm{~b}$ & $5,10 \mathrm{bc}$ & $5,06 \mathrm{c}$ \\
\hline 3 & $\mathbf{K}_{2}$ & $\begin{array}{l}21,14 \\
\text { ab }\end{array}$ & $4,65 \mathrm{a}$ & $4,65 a b$ & $2,32 \mathrm{~b}$ \\
\hline 4 & $\mathbf{K}_{\mathbf{3}}$ & 19,35 a & 4,38 a & 2,86 a & 1,14 a \\
\hline & $\mathbf{B N J}_{0,05}$ & $\mathbf{9 , 5 5}$ & 1,67 & 1,89 & 1,01 \\
\hline
\end{tabular}

Keterangan: Angka yang diikuti dengan huruf yang sama pada kolom yang sama berbeda tidak nyata pada taraf kepercayaan $95 \%$.

Dari Tabel 2 dapat dijelaskan bahwa, rata-rata intensitas serangan hama Epilachna sp akibat konsentrasi ekstrak biji jengkol terendah dijumpai pada perlakuan $\mathrm{K}_{3}$ yaitu $19,35 \% ; 4,38 \% ; 2,86 \%$ dan $1,14 \%$, dan tertinggi dijumpai pada perlakuan $\mathrm{K}_{0}$ yaitu $61,91 \% ; 7,99 \%, 6,73 \%$ dan $7,93 \%$.

Hal ini diduga pemberian ekstrak biji jengkol konsentrasi tinggi (hingga $60 \%$ ) lebih efektif dalam mengendalikan serangan hama Epilachna sp. Semakin tinggi konsentrasi ekstrak biji jengkol yang diberikan, maka semakin tinggi kemampuan pestisida nabati dalam mengendalikan hama yang dapat berakibat pada terhambatnya perkembangan hama. Menurut Prijono (1999) bahwa, ekstrak yang tidak aktif pada konsentrasi rendah mungkin disebabkan karena senyawa yang terkandung di dalamnya kurang aktif atau senyawa tersebut sebenarnya cukup aktif tetapi kandungannya rendah.

\section{Jumlah Hama Epilachna sp yang Mati}

Hasil analisis sidik ragam (Tabel Lampiran 10, 12, 14 dan 16) menunjukan bahwa konsentrasi ekstrak biji jengkol berpengaruh sangat nyata terhadap jumlah 
Epilachna sp yang mati pada umur 30, 40, 50 dan 60 HST. Rata-rata jumlah hama Epilachna sp yang mati akibat konsentrasi ekstrak biji jengkol dapat dilihat pada tabel berikut.

Tabel 3. Rata-Rata Jumlah Hama Epilachna sp yang Mati (Ekor) pada Umur 30, 40, 50 dan 60 HST akibat Konsentrasi Ekstrak Biji Jengkol.

\begin{tabular}{|c|c|c|c|c|c|}
\hline \multirow{2}{*}{ No } & \multirow{2}{*}{ Perlakuan } & \multicolumn{4}{|c|}{$\begin{array}{c}\text { Jumlah Hama Epilachna sp yang } \\
\text { Mati }\end{array}$} \\
\hline & & $\begin{array}{c}30 \\
\text { HST }\end{array}$ & $\begin{array}{c}40 \\
\text { HST }\end{array}$ & $\begin{array}{c}50 \\
\text { HST }\end{array}$ & $\begin{array}{c}60 \\
\text { HST }\end{array}$ \\
\hline 1 & $\mathbf{K}_{\mathbf{0}}$ & 0,71 a & 0,71 a & 0,71 a & 0,71 a \\
\hline 2 & $\mathbf{K}_{1}$ & 0,71 a & 0,71 a & 0,71 a & 0,71 a \\
\hline 3 & $\mathbf{K}_{\mathbf{2}}$ & 0,84 b & 0,97 b & $1,10 \mathrm{~b}$ & $1,22 \mathrm{~b}$ \\
\hline 4 & $\mathbf{K}_{3}$ & $1,54 \mathrm{c}$ & $1,21 \mathrm{c}$ & $1,43 \mathrm{c}$ & $1,54 \mathrm{c}$ \\
\hline & BNJ $J_{0,05}$ & 0,12 & 0,17 & 0,17 & 0,12 \\
\hline
\end{tabular}

Keterangan: Angka yang diikuti dengan huruf yang sama pada kolom yang sama berbeda tidak nyata pada taraf kepercayaan $95 \%$.

Dari Tabel 3 dapat dijelaskan bahwa, rata-rata jumlah hama Epilachna sp yang mati pada umur 30, 40, 50 dan 60 HST akibat konsentrasi ekstrak biji jengkol tertinggi dijumpai pada perlakuan K3 (60 \%) yaitu 1,54 ekor; 1,21 ekor; 1,43 ekor dan 1,54 ekor, diikuti oleh perlakuan K2, K1 dan K0. Sedangkan terendah dijumpai pada perlakuan K0 dan K1 yaitu 0,71 ekor.

Semakin tinggi jumlah hama Epilachna sp yang mati maka semakin rendah intensitas serangan. Hal ini tidak terlepas dari kandungan bahan aktif yang terdapat pada pestisida nabati yang digunakan. Menurut Elysa (2011) bahwa biji jengkol mengandung senyawa alkaloid, saponin, flavonoids, glikosida, saponin dan tannin, yang ampuh untuk melindungi tanaman dari serangan hama. Lebih lanjut Dadang (1999) menyatakan bahwa, senyawa-senyawa yang terdapat dalam tumbuhan (nabati) dapat menunjukkan berbagai aktifitas biologi pada serangga melalui proses penghambatan /penolak makan, penolak peneluran, penghambat pertumbuhan dan perkembangan yang akhirnya dapat mengakibatkan kematian.

Selanjutnya, Adnyana et al. (2012) menyatakan bahwa tinggi rendahnya tingkat efikasi sangat dipengaruhi oleh besar dan kecilnya konsentrasi yang digunakan dan besarnya konsentrasi berbanding lurus dengan tingginya persentase mortalitas dimana semakin tinggi konsentrasi maka semakin tinggi juga persentase mortalitas.

\section{Tinggi Tanaman}

Hasil analisis sidik ragam (Tabel Lampiran 18, 20, 22 dan 24) menunjukan bahwa konsentrasi ekstrak biji jengkol berpengaruh sangat nyata terhadap rata-rata tinggi tanaman terong umur 50 dan 60 HST, namun tidak berpengaruh nyata terhadap tinggi tanaman umur 30 dan 40 HST. Ratarata tinggi tanaman terong akibat konsentrasi ekstrak biji jengkol dapat dilihat pada tabel berikut.

Tabel 4. Rata-Rata Tinggi Tanaman Umur 30, 40, 50 dan 60 HST (cm) akibat Konsentrasi Ekstrak Biji Jengkol

\begin{tabular}{|c|c|c|c|c|c|}
\hline \multirow{2}{*}{ No } & \multirow{2}{*}{ Pertakaas } & \multicolumn{4}{|c|}{ Tingel Tasaman (cm) } \\
\hline & & $30 \mathrm{HST}$ & 40 HST & $50 \mathrm{HST}$ & 60 HST \\
\hline 1 & $\mathbf{K}_{0}$ & 49,06 & $64.25 \mathrm{a}$ & $89,38 \mathrm{a}$ & 91,06 a \\
\hline 2 & $\mathbf{K}_{3}$ & 53,44 & 66,75 ab & 90,44 a & $92,4 \mathrm{a}$ \\
\hline 3 & $\mathbf{K}_{\mathrm{s}}$ & 52,88 & 68,56 ab & $94,88 \mathrm{~b}$ & 96,38 a \\
\hline 4 & Ks & 56,13 & $71,44 \mathrm{~b}$ & $106,06 \mathrm{c}$ & $120,75 \mathrm{~b}$ \\
\hline \multicolumn{2}{|r|}{ BNJ $_{0,4}$} & - & 6,85 & 4,28 & 6,65 \\
\hline
\end{tabular}

Keterangan : Angka yang diikuti dengan huruf yang sama pada kolom yang sama berbeda tidak nyata pada taraf kepercayaan $95 \%$.

Dari Tabel 4 dapat dijelaskan bahwa, rata-rata tinggi tanaman umur 40, 50 dan 60 HST akibat konsentrasi ekstrak biji jengkol tertinggi dijumpai pada perlakuan K3 $(60 \%)$ yaitu $71,44 \mathrm{~cm} ; 106,06 \mathrm{~cm}$ dan $120,75 \mathrm{~cm}$, diikuti oleh perlakuan K2, K1 dan K0. Sedangkan terendah dijumpai pada perlakuan K0 yaitu $64,25 \mathrm{~cm} ; 89,38 \mathrm{~cm}$ dan 91,06 cm. Hal ini diduga pemberian ekstrak biji jengkol menyebabkan sedikitnya gangguan serangan 
hama sehingga tanaman dapat tumbuh optimal.

Biji jengkol juga bersifat alelopati terhadap gulma yang menjadi pesaing unsur hara dengan tanaman terong, dimana pada perlakuan K3 pertumbuhan gulma sangat sedikit sehingga unsur hara dapat diserap lebih optimal oleh tanaman terong. Alelopati adalah interaksi biokimia antara tumbuhan dengan tumbuhan lain yang mengakibatkan penekanan pertumbuhan dan perkembangan baik secara langsung maupun tidak langsung melalui senyawa kimia atau alelokimia (Kalinova, 2010). Selain itu, biji jengkol mengandung senyawa flavonoid yang dapat bekerja sebagai pengatur tumbuh, pengatur fotosintesis, antimikroba dan antivirus (Rahmat, 2009). Pertambahan tinggi tanaman merupakan hasil kerja dari auksin yang terkandung dalam ekstrak biji jengkol.

\section{Pengaruh Waktu Aplikasi}

\section{Intensitas Serangan Hama Epilachna sp}

Hasil analisis sidik ragam (Tabel Lampiran 2, 4, 6 dan 8) menunjukan bahwa waktu aplikasi berpengaruh sangat nyata terhadap rata-rata intensitas serangan hama Epilachna sp pada tanaman terong umur 40, 50 dan 60 HST, berpengaruh nyata terhadap rata-rata intensitas serangan hama Epilachna sp pada tanaman terong umur 30 HST. Ratarata intensitas serangan hama Epilachna sp pada tanaman terong akibat waktu aplikasi dapat dilihat pada tabel berikut.

Tabel 5. Rata-Rata Intensitas Serangan Hama Epilachna sp (\%) akibat Waktu Aplikasi

\begin{tabular}{|c|c|c|c|c|c|}
\hline \multirow{2}{*}{ No } & \multirow{2}{*}{ Prtalian } & \multicolumn{4}{|c|}{ Intrasitas Serabgan (\$6) } \\
\hline & & $30 \mathrm{HST}$ & 4ล HSI & $50 \mathrm{HSI}$ & 6 सSI \\
\hline 1 & $\mathbf{W}_{1}$ & 26,122 & $4.21 \mathrm{a}$ & 3.112 & 3,23, \\
\hline 2 & $w_{2}$ & 33,42 ab & 5,17 ab & 3,93 ab & $3,82 b$ \\
\hline 3 & w, & 3481 ab & $6,4.4 \mathrm{~b}$ & $5,64 \mathrm{bc}$ & $3,96 \mathrm{~b}$ \\
\hline \multirow[t]{2}{*}{4} & $w_{4}$ & $3867 \mathrm{~b}$ & $8,27 c$ & $6.66 \mathrm{c}$ & 5,516 \\
\hline & BNhis & 9,55 & 1,67 & 1.59 & $1,1,1$ \\
\hline
\end{tabular}

Berdasarkan data pada Tabel 5 dapat dijelaskan bahwa, rata-rata intensitas serangan akibat waktu aplikasi terendah dijumpai pada perlakuan W1 yaitu $26,12 \%$;
$4,21 \% ; 3,11 \%$ dan $3,23 \%$. Sedangkan tertinggi dijumpai pada perlakuan $\mathrm{W} 4$, yaitu $38,67 \% ; 8,27 \% ; 6,66 \%$ dan 5,51\%. Dengan demikian semakin cepat dilakukan pengendalian maka semakin rendah intensitas serangannya.

Pengendalian yang dilakukan sejak awal dapat mengurangi intensitas serangan hama Epilachna sp. Hal ini diduga tingkat serangan belum menyebabkan tingkat kerusakan ekonomi atau luka ekonomi. Berkenaan dengan kaitan antara efektivitas pemberian pestisida nabati, Wahyuno et al (2009) menyatakan bahwa efektivitas pestisida nabati sangat ditentukan oleh ketepatan waktu aplikasi.

\section{Jumlah Epilachna sp yang Mati}

Hasil analisis sidik ragam (Tabel Lampiran 10, 12, 14 dan 16) menunjukan bahwa waktu aplikasi berpengaruh sangat nyata terhadap rata-rata jumlah Epilachna sp yang mati pada umur tanaman 30, 40, dan 50 HST, namun tidak berpengaruh nyata terhadap jumlah Epilachna yang mati pada umur 60 HST. Rata-rata jumlah Epilachna sp yang mati akibat waktu aplikasi dapat dilihat pada tabel berikut.

Tabel 6. Rata-Rata Jumlah Epilachna sp yang Mati (ekor) pada Umur 30, 40, 50, dan 60 HST akibat Waktu Aplikasi

\begin{tabular}{cccccc}
\hline \multirow{2}{*}{$N_{0}$} & \multirow{2}{*}{ Perlakuan } & \multicolumn{5}{c}{ Jumbab Epilacha sp yang Mati (ekor) } \\
\cline { 3 - 6 } & & 30 HST & 40 HST & 50 HST & 60 HST \\
\hline 1 & $\mathrm{~W}_{1}$ & $1,06 \mathrm{~b}$ & $1,06 \mathrm{~b}$ & $1,06 \mathrm{~b}$ & 1,06 \\
2 & $\mathrm{~W}_{2}$ & $0,88 \mathrm{a}$ & $1,06 \mathrm{~b}$ & $1,06 \mathrm{~b}$ & 1,06 \\
3 & $\mathrm{~W}_{3}$ & $0,93 \mathrm{ab}$ & $0,77 \mathrm{a}$ & $1,06 \mathrm{~b}$ & 1,06 \\
4 & $\mathrm{~W}_{4}$ & $0,93 \mathrm{ab}$ & $0,71 \mathrm{a}$ & $0,77 \mathrm{a}$ & 1,01 \\
\hline & $\mathrm{BNJ}_{6,05}$ & 0,12 & 0,17 & 0,17 & - \\
\hline
\end{tabular}

Keterangan : Angka yang diikuti dengan huruf yang sama pada kolom yang sama berbeda tidak nyata pada taraf kepercayaan $95 \%$.

Berdasarkan data pada Tabel 6 dapat dijelaskan bahwa rata-rata jumlah Epilachna sp yang mati pada umur 30 HST akibat waktu aplikasi terbanyak dijumpai pada perlakuan 
W1 yaitu 1,06 ekor dan yang terendah dijumpai pada perlakuan W2 yaitu 0,88 ekor. Pada umur 40 HST, terbanyak dijumpai pada perlakuan W1 dan W2 yaitu 1,06 ekor dan yang terendah dijumpai pada perlakuan W4 yaitu 0,71 ekor. Pada umur 50 HST terbanyak dijumpai pada perlakuan $\mathrm{W} 1, \mathrm{~W} 2$ dan W3 yaitu 1,06 ekor dan yang terendah dijumpai pada perlakuan W4 yaitu 0,77 ekor.

Pemberian ekstrak biji jengkol yang dilakukan sejak dini lebih efektif dalam mengendalikan hama Epilachna sp pada tanaman terong. Hal ini disebabkan ekstrak biji jengkol mengandung bahan aktif saponin, tanin, flavonoid dan alkaloid yang ampuh untuk melindungi tanaman dari serangan hama (Suwarsi, 2002). Agar diperoleh mortalitas hama yang tinggi maka sebaiknya dilakukan pada saat yang tepat. Menurut Sudarsono (2006) menyatakan bahwa, waktu penyemprotan harus diperhatikan sesuai dengan siklus perkembangan hama dan penyakit.

\section{Tinggi Tanaman}

Hasil analisis sidik ragam (Tabel Lampiran 18, 20, 22 dan 24) menunjukan bahwa waktu aplikasi berpengaruh sangat nyata terhadap tinggi tanaman umur 50 HST dan 60 HST, berpengaruh nyata terhadap tinggi tanaman umur $30 \mathrm{HST}$, namun tidak berpengaruh nyata terhadap tinggi tanaman umur 40 HST. Rata-rata tinggi tanaman akibat waktu aplikasi dapat dilihat pada tabel berikut.

Tabel 7. Rata-Rata Tinggi Tanaman Umur 30, 40, 50 dan 60 HST akibat Waktu Aplikasi

\begin{tabular}{|c|c|c|c|c|c|}
\hline \multirow{2}{*}{$\mathrm{N}_{0}$} & \multirow{2}{*}{ Perlakuan } & \multicolumn{4}{|c|}{ Tingei Tanaman (cm) } \\
\hline & & 30 HST & 40 HST & 50 HST & 60 HST \\
\hline 1 & $W_{1}$ & 57,75 a & 68,31 & $101,44 \mathrm{~b}$ & $108,88 \mathrm{~b}$ \\
\hline 2 & $W_{2}$ & $50,19 \mathrm{a}$ & 69,94 & $92,63 \mathrm{a}$ & $97,50 \mathrm{a}$ \\
\hline 3 & $W_{3}$ & $51,06 \mathrm{a}$ & 66,25 & 94,63 a & 99,88 a \\
\hline 4 & $W_{4}$ & $52.50 \mathrm{a}$ & 66,50 & $92,06 \mathrm{a}$ & $94,38 \mathrm{a}$ \\
\hline & BNJus & 9,29 & . & 4.28 & 6,65 \\
\hline
\end{tabular}

huruf yāng samā pada ǩolom yang sāma berbeda tidak nyata pada taraf kepercayaan $95 \%$.
Berdasarkan data pada Tabel 7 dapat dijelaskan bahwa rata-rata tinggi tanaman akibat waktu aplikasi tertinggi dijumpai pada perlakuan W1 yaitu $57,75 \mathrm{~cm} ; 101,44 \mathrm{~cm}$ dan $108,88 \mathrm{~cm}$, yang terendah dijumpai pada perlakuan W4 yaitu 92,06 cm dan 94,38 cm.

Pemberian ekstrak biji jengkol selain dapat mengendalikan hama Epilachna sp juga dapat meningkatkan pertumbuhan tanaman terong. Hal ini disebabkan adanya unsur hara yang terkandung dalam biji jengkol, seperti $\mathrm{N}, \mathrm{P}, \mathrm{K}, \mathrm{Ca}, \mathrm{Fe}$, dan $\mathrm{S}$. Unsur $\mathrm{N}$ sangat diperlukan pada pertumbuhan vegetatif tanaman termasuk pertumbuhan tinggi tanaman. Selain itu, biji jengkol juga mengandung flavonoid yang berfungsi sebagai pengatur tumbuhan, pengatur fotosintesis, bersifat antimikroba dan antivirus pada tanaman, sehingga aplikasinya mampu meningkatkan pertumbuhan tanaman. Dengan demikian, hasil penelitian ini mendukung pernyataan Masriadi (2013) bahwa aplikasi herbisida ekstrak kulit biji jengkol berpengaruh sangat nyata terhadap tinggi tanaman, indek luas daun, lingkaran tongkol, bobot tongkol pertanaman, bobot tongkol perplot, hasil perhektar, persentase kematian gulma dominan, berat kering gulma dominan, dan persentase penurunan hasil akibat serangan gulma.

\section{Pengaruh Interaksi}

Hasil analisis sidik ragam (Tabel Lampiran 2, 4, 6 dan 8) menunjukan bahwa terdapat interaksi konsentrasi ekstrak biji jengkol dan waktu aplikasi yang sangat nyata terhadap intensitas serangan hama Epilachna pada tanaman terong umur $60 \mathrm{HST}$, namun tidak berpengaruh nyata terhadap intensitas serangan pada umur 30, 40 dan 50 HST.

Terdapat interaksi yang sangat nyata terhadap jumlah hama Epilachna sp yang mati pada umur 30, 40 dan $50 \mathrm{HST}$, namun tidak terdapat interaksi terhadap jumlah hama Epilachna sp yang mati pada umur 60 HST (Tabel Lampiran 10, 12, 14 dan 16).

Terdapat interaksi yang sangat nyata terhadap tinggi tanaman terong umur 50 dan 60 HST, namun tidak terdapat interaksi 
terhadap tinggi tanaman umur 30 dan 40 HST (Tabel Lampiran 18, 20, 22 dan 24).

Rata-rata intensitas serangan hama Epilachna, jumlah hama Epilachna sp yang mati akibat interaksi dapat dilihat pada tabel berikut.

Tabel 8. Rata-Rata Intensitas Serangan (\%) dan Jumlah Hama Epilachna yang Mati (Ekor) akibat Interaksi.

\begin{tabular}{|c|c|c|c|c|c|c|c|c|}
\hline \multirow{3}{*}{$\begin{array}{l}\text { Kantizasi } \\
\text { Perhateus }\end{array}$} & \multicolumn{4}{|c|}{ Intenittu Serangu } & \multicolumn{4}{|c|}{ 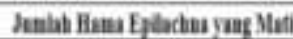 } \\
\hline & 30 & 40 & 50 & 60 & 30 & 4 & 50 & $6 t$ \\
\hline & \multicolumn{8}{|c|}{ HST } \\
\hline$k_{1} W_{1}$ & 6.53 & 7,98 & 5,51 & $5,81 \mathrm{~cd}$ & 0,713 & 0,712 & 4,714 & 4,71 \\
\hline $\mathbf{K}_{4} W_{z}$ & 64,94 & 6.58 & 5,58 & $6,22 \mathrm{dd}$ & 0,71, & 0,712 & 0,711 & 0,71 \\
\hline $\mathrm{E}_{4} \mathrm{~W}_{3}$ & 61,10 & 8.64 & 7,85 & 3,450 & 0,71 & 871. & 0,71, & 0,71 \\
\hline$K_{i} W_{i}$ & 61,18 & 876 & 7,30 & $12,25 t$ & 0,71 & 6,712 & 0,714 & 0,7 \\
\hline$K_{1} W_{1}$ & $\mathbf{S}, 10$ & 464 & 3,43 & $4,46 \mathrm{bc}$ & 0,71 & 0,712 & 0,714 & 0,7 \\
\hline$K_{i} W_{1}$ & 26,57 & 659 & 4,40 & $5,48 \mathrm{dd}$ & 0,71 & 6,711 & 0,71 & 0,71 \\
\hline $\mathrm{K}_{j} \boldsymbol{W}_{j}$ & 29,76 & 6,96 & 5,31 & $4,95 \mathrm{~cd}$ & 0,713 & 6,712 & $0,71:$ & $0, \pi 1$ \\
\hline$K_{j} W_{i}$ & 41,18 & 836 & 7,25 & $53 \mathrm{~cd}$ & 0,71 . & 0,712 & 0,71 & $0, \pi$ \\
\hline $\mathrm{K}_{3} \mathbf{W}_{1}$ & 13,57 & 254 & 2.80 & 237 ab & $1 \mathrm{nb}$ & $1,22 \mathrm{~b}$ & 1,228 & $1, n$ \\
\hline$K_{z} W_{z}$ & 2,38 & 419 & 3,34 & $2,34 \mathrm{ab}$ & 0,71 . & $1,12 \mathrm{~b}$ & $1,21 \mathrm{~b}$ & 1,22 \\
\hline$k_{j} W_{3}$ & 24,18 & 487 & 6,01 & $183 \mathrm{a}$ & 0,7, & 2718 & 1,221 & 1.21 \\
\hline $\mathbf{K} ; \mathbf{W}_{i}$ & 24,43 & 7月? & 6,55 & $2,77 \mathrm{ah}$ & $0,71 \mathrm{~s}$ & $0,71$. & $4 \pi 13$ & 1,2 \\
\hline$k_{j} W_{1}$ & 53 & 1, Al & 0,53 & $0,30 \mathrm{a}$ & $1,38 \mathrm{c}$ & $158 \mathrm{t}$ & $1,54 \mathrm{t}$ & 1,5 \\
\hline $\mathbf{k}_{\mathbf{j}} \mathbf{W}_{\mathbf{z}}$ & $19 \$$ & 3,2 & 1,59 & 1,262 & $1,40 \mathrm{bc}$ & $158 \mathrm{c}$ & $155 t$ & 1,8 \\
\hline $\mathrm{K}_{j} W_{3}$ & 24,31 & 3,6 & 3,99 & $131 \mathrm{a}$ & LSSIC & $097 \mathrm{at}$ & $155 \mathrm{t}$ & 1,58 \\
\hline $\mathrm{K}_{j} \mathrm{~W}_{i}$ & 2890 & 87 & 5,15 & 1.992 & 1.58 & 271. & c.96 ab & 1.40 \\
\hline BNJys & 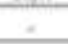 & . & 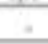 & $25 !$ & 023 & 0.33 & 0,3 & . \\
\hline
\end{tabular}

Keterangan: Angka yang diikuti dengan huruf yang sama pada kolom yang sama berbeda tidak nyata pada taraf kepercayaan $95 \%$.

Berdasarkan data pada Tabel 8 dapat dijelaskan bahwa, rata-rata intensitas serangan terendah akibat interaksi dijumpai pada perlakuan $\mathrm{K}_{3} \mathrm{~W}_{1}$ yaitu $0,30 \%$; Sedangkan tertinggi dijumpai pada kombinasi perlakuan $\mathrm{K}_{0} \mathrm{~W}_{4}$, yaitu 12,25\%.

Rata-rata jumlah hama Epilachna sp yang mati akibat interaksi tertinggi dijumpai pada kombinasi perlakuan $\mathrm{K}_{3} \mathrm{~W}_{1}$ dan $\mathrm{K}_{3} \mathrm{~W}_{2}$ yaitu 1,58 ekor.

Rata-rata tinggi tanaman terong akibat interaksi dapat dilihat pada tabel berikut.

Tabel 9. Rata-Rata Tinggi Tanaman Terong (cm) akibat Interaksi

\begin{tabular}{|c|c|c|c|c|}
\hline \multirow{3}{*}{$\begin{array}{l}\text { Ketubinasi } \\
\text { Perlakinan }\end{array}$} & \multicolumn{4}{|c|}{ Tlagt Tanaman (cm) } \\
\hline & 30 & 40 & 50 & 60 \\
\hline & \multicolumn{4}{|c|}{ HST } \\
\hline $\mathbf{K}_{6} \mathbf{W}_{1}$ & 47,50 & 60.75 & $88,75 \mathrm{x}$ & $90,25 \mathrm{a}$ \\
\hline $\mathbf{K}_{\mathbf{0}} \mathbf{W}_{2}$ & 47,50 & 67,75 & $90,00 \mathrm{a}$ & $91.50 \mathrm{a}$ \\
\hline $\mathbf{K}_{\mathrm{a}} \mathbf{W}_{3}$ & 51,00 & 61,50 & $88,50=$ & $91,00 \mathrm{a}$ \\
\hline $\mathbf{K}_{6} \mathbf{W}_{4}$ & 50,25 & 67,00 & $90,25 \mathrm{a}$ & $91.50 \mathrm{a}$ \\
\hline $\mathbf{K}_{1} \mathbf{W}_{1}$ & 53,25 & 66,50 & $91,50 \mathrm{ab}$ & 93,00 a \\
\hline $\mathbf{K}_{1} \mathbf{W}_{2}$ & 54,00 & 68,00 & $90,25 \mathrm{a}$ & $91.75 \mathrm{a}$ \\
\hline $\mathbf{K}_{1} \mathbf{W}_{3}$ & 55,00 & 67,75 & 89,75 a & $91.25 \mathrm{a}$ \\
\hline $\mathbf{K}_{1} \mathbf{W}_{4}$ & 51,50 & 64,75 & $90,25 \mathrm{a}$ & 93,75 a \\
\hline $\mathbf{k}_{3} \mathbf{W}_{1}$ & 61.75 & 70,75 & 95,50 abe & $94,75 \mathrm{a}$ \\
\hline $\mathbf{K}_{\mathbf{2}} \mathbf{W}_{2}$ & 51,25 & 70,75 & $91,00 \mathrm{ab}$ & 94,25 a \\
\hline $\mathbf{K}_{2} \mathbf{W}$, & 44,00 & 65,75 & $101,00 \mathrm{\kappa}$ & $102,50 \mathrm{ab}$ \\
\hline $\mathbf{K}_{\mathbf{2}} \mathbf{W}_{4}$ & 54,50 & 67,00 & $92,00 \mathrm{ab}$ & $94,00 \mathrm{a}$ \\
\hline $\mathbf{K}, \mathbf{W}_{1}$ & 68,50 & 75,25 & $130,00 \mathrm{~d}$ & $157,50 \mathrm{e}$ \\
\hline $\mathbf{K}, \mathbf{W}$; & 48,00 & 73.25 & $99,25 \mathrm{bc}$ & $112,50 \mathrm{~b}$ \\
\hline $\mathbf{K}, \mathbf{W}$, & 54,25 & 70,00 & 99,25 be & $114,75 \mathrm{~b}$ \\
\hline $\mathbf{K}_{3} \mathbf{W}_{4}$ & 53,75 & 67,25 & $95,75 \mathrm{abc}$ & 98.25 a \\
\hline $\mathrm{BNJ}_{\text {2is }}$ & 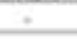 & + & 8,28 & 12.88 \\
\hline
\end{tabular}

Keterangan: Angka yang diikuti dengan huruf yang sama pada kolom yang sama berbeda tidak nyata pada taraf kepercayaan $95 \%$.

Dari tabel 9 dapat dijelaskan bahwa, rata-rata tanaman tertinggi akibat interaksi dijumpai pada kombinasi perlakuan $\mathrm{K}_{3} \mathrm{~W}_{1}$ yaitu $130,00 \mathrm{~cm}$ dan $157,50 \mathrm{~cm}$.

Dari hasil penelitian ini menunjukkan bahwa semakin tinggi konsentrasi ekstrak biji jengkol yang dikombinasikan dengan waktu aplikasi sejak dini mengakibatkan semakin rendah intensitas serangan dan semakin banyak jumlah hama Epilachna sp yang mati. Hal ini disebabkan semakin banyak bahan aktif ekstrak yang digunakan maka daya racunnya akan semakin besar. Natawigena (2000) menyatakan bahwa setiap mahluk hidup mempunyai batas toleransi terhadap racun dimana mahluk tersebut tidak mati. Lewat batas tersebut akan menimbulkan kematian pada mahluk hidup yang diuji. Proses kematian akan semakin cepat dengan pertambahan dosis racun yang digunakan. Lebih lanjut, Hasanuddin et al (2008) menyatakan bahwa, pestisida nabati umumnya memiliki toksisitas rendah dibanding dengan pestisida sintetik dan bersifat revelen serta memiliki antifidan mencegah serangga memakan tanaman yang telah disemprot terutama disebabkan rasanya yang pahit.

Penurunan intensitas serangan dan populasi hama Epilachna sp merupakan 
pengaruh dari penyemprotan ekstrak biji jengkol yang dilakukan sejak dini, sehingga pada akhirnya akan meningkatkan pertumbuhan tanaman terong. Pertumbuhan tanaman terong lebih baik pada pemberian ekstrak biji jengkol dosis tinggi. Hal ini diduga jengkol mengandung unsur hara yang dibutuhkan tanaman terong untuk menunjang pertumbuhannya. Menurut Ajie et al (2014) bahwa, jengkol mengandung unsur hara berupa $\mathrm{N}, \mathrm{P}, \mathrm{K}, \mathrm{Ca}$, dan $\mathrm{Mg}$ sehingga selain bermanfaat sebagai pestisida, ekstrak jengkol juga dapat mempengaruhi pertumbuhan tanaman karena kandungan hara yang dimilikinya.

\section{KESIMPULAN DAN SARAN}

\section{Kesimpulan}

1. Konsentrasi ekstrak biji jengkol berpengaruh sangat nyata terhadap intensitas serangan hama Epilachna sp, jumlah hama Epilachna sp yang mati, dan tinggi tanaman terong umur 50 dan 60 HST, berpengaruh nyata terhadap tinggi tanaman terong umur $40 \mathrm{HST}$, terbaik dijumpai pada perlakuan $\mathrm{K}_{3}(60 \%)$.

2. Waktu aplikasi ekstrak biji jengkol berpengaruh sangat nyata terhadap intensitas serangan hama Epilachna sp pada umur 40, 50 dan 60 HST, jumlah hama Epilachna sp yang mati pada umur 30, 40 dan 50 HST, tinggi tanaman umur 50 dan 60 HST, berpengaruh nyata terhadap intensitas serangan hama Epilachna sp dan tinggi tanaman umur 30 HST, terbaik dijumpai pada perlakuan $\mathrm{W}_{1}$ (waktu aplikasi 20 HST).

3. Terdapat interaksi yang sangat nyata terhadap intensitas serangan hama Epilachna sp pada umur 60 HST, jumlah hama Epilachna sp yang mati pada umur 30, 40 dan 50 HST, dan tinggi tanaman umur 50 dan 60 HST, terbaik dijumpai pada perlakuan $\mathrm{K}_{3} \mathrm{~W}_{1}$ (konsentrasi ekstrak biji jengkol $60 \%$ dan waktu aplikasi 20 HST).

\section{Saran}

1. Ekstrak biji jengkol konsentrasi $60 \%$ dapat menurunkan intensitas serangan hama Epilachna sp, oleh karena itu dianjurkan penggunaannya pada budidaya tanaman, khususnya tanaman terong.

2. Perlu dilakukan penelitian lebih lanjut untuk mengetahui pengaruh ekstrak biji jengkol pada berbagai dosis dan jenis tanaman lainnya.

\section{DAFTAR PUSTAKA}

Ajie, D. Wardhanu, G.K. Phungghalawati, E. Wananto dan A.Yusuf. 14 Tukul Jengkol Untuk $\wedge$ ingkatkan Produktivitas Padi Organik. Stcientific Repsitory. http:// repository.ipb.ac/handle/123456789/ 74114

Arifin, Ridwan Nur.2014. Pembuatan Pastisida Alami, Campuran Ekstrak Daun Mindi (Melia azedarach L.) dan Kulit Buah Jengkol (Pithecellobium jiringa) Untuk Mengendalikan Ulat Biji (Tenebrio molitor). Skripsi. Universitas Muhammadiyah Surakarta.

Anwar, R., Prihanani, R. Aswardi. 2013. Uji Berbagai Dosis Ekstrak Kulit Jengkol Terhadap Pertumbuhan Gulma Echinochloa cruss-galli(L) Beauv. http://agroqua.unihaz.ac.id/index.php /e-journal-1/func-startdown/64/. Diakses tanggal 05 Mei 2015

Atiwasiati, 2005. Pedoman Pengenalan dan Pengendalian Organisme Pengganggu Tumbuhan pada Tanaman Kacang-kacangan dn Umbi-umbian. Direktorat Jenderal Tanaman Pangan. Jakarta.

Budiman, E., 2005. Cara dan Upaya Budidaya Terong. Wahana Iptek Bandung. Bandung.

Elysa. 2011. Uji Efek Ekstrak Etanol Biji Jengkol (Pithecellobium lobatum 
Benth) Terhadap Penurunan Kadar Glukosa Darah Tikus Putih Jantan Galur Wistar Yang diinduksi Aloksan. Skripsi. Universitas Sumatera Utara. Medan.

Gunawan, D. dan Mulyani, S. 2004. Ilmu Obat Alam (Farmakognosi) Jilid I. Penebar Swadaya. Jakarta.

Harborne, J. B. 1987.Metode Fitokimia: Penuntun Cara Modern Menganalisis Tumbuhan. Penerbit ITB. Bandung.

Haryono, Semangun. 1998. Bertanam Terung. Kanisius. Yogyakarta.

Hutapea, J.R. 1994. Inventaris Tanaman Obat Indonesia III. Departemen Kesehatan RI. Jakarta.

Jumar. 2000. Entomologi Pertanian. Rineka Cipta. Jakarta.

Kalinova, J. 2010. Allelopathy and Organic Farming Sustainable Agriculture Reviews 3. Springer Science. UK.

Kardinan, A. 2005. Pestisida Nabati Ramuan dan Aplikasi. Penebar Swadaya, Jakarta.

Mashudi. 2010. Budidaya Terung. Azka Press. Jakarta

Masriadi. 2013. Pengaruh Herbisida Ekstrak Kulit Buah Jengkol Terhadap Pertumbuhan dan Hasil Tanaman Jagung Manis. Jurnal Hasil Penelitian Fakultas Pertanian Universitas Taman Siswa Padang. www.journal.unitas-pdg.ac.ic. Diakses tangga 05 Mei 2015.
Nurussakinah. 2010. Skrinning Fitokimia dan Uji Aktivitas Antibakteri Ekstrak Kulit Buah Tanaman Jengkol (Pithecellobium jiringa (Jack) Prain) Terhadap Bakteri Streptococcus mutans,

Staphylococcus aureus dan Eschericia coli. Skripsi. Fakultas Farmasi, USU, Medan.

Pitojo, S. 1994. Jengkol: Budidaya dan Pemanfaatannya. Kanisius. Yogyakarta.

Rahmat, H. 2009. Identifikasi Senyawa Flavonoid pada Sayuran Indigenous Jawa Barat. Skripsi. Fakultas Teknologi Pertanian. IPB. Bogor.

Roswaty,A. 2010. All About Jengkol and Petai. Gramedia Pustaka Utama. Jakarta.

Sudarmo. 1999. Pestisida Nabati, Pembuatan dan Pemanfaatannya. Penerbit Kanisius. Yogyakarta.

Suhendro, M. Kusnawiria, I. Zulkanaen, A. Triwiyono, T.K. Moekasan, L. Prabaningrum. 2000. Hama dan Penyakit Utama Tanaman Cabai dan Pengendaliannya. Dalam Balitsa

Tjitrosoepomo, G. 2005. Morfologi Tumbuhan. UGM Press. Yogyakarta.

Wahyuno, Herlina D dan M.Reza. 2009. Pengaruh Pestisida Nabati Terhadap Pertumbuhan Tanaman Budidaya. Jurnal Hortikultura 